\title{
KEMAMPUAN MENYIMPULKAN ISI BERITA SISWA KELAS VIII SMP NEGERI 1 BARANGKA KABUPATEN MUNA BARAT Oleh
}

\author{
Kalimudin $^{1}$, Aris Badara ${ }^{2}$, dan Sahlan ${ }^{3}$ \\ ${ }^{1}$ Alumni Jurusan Pend. Bahasa dan Sastra Indonesia, ${ }^{2,3}$ Dosen Jurusan Pendidikan Bahasa dan \\ Sastra Indonesia, Fakultas Keguruan dan Ilmu Pendidikan \\ Universitas Halu Oleo
}

\begin{abstract}
ABSTRAK
Tujuan penelitian ini adalah untuk mendeskripsikan kemampuan menyimpulkan isi berita siswa kelas VIII SMP Negeri I Barangka Tahun Pelajaran 2018/2019.Jenis penelitian yang digunakan dalam penelitian ini tergolong dalam penelitian lapangan. Peneliti terjun langsung untuk melakukan penelitian dilapangan tempat meneliti (sekolah) untuk memperoleh keabsahan data.Metode yang digunakan dalam penelitian ini adalah deskriptif kuantitatif yaitu penelitian yang memberikan gambaran secara jelas tentang kemampuan menyimpulkan isi berita siswa kelas VIII SMP Negeri I Barangka yang selanjutnya akan dianalisis secara kuantitatif menggunakan statistik presentase yang berupa angka-angka. Adapun responden penelitian pada penelitian ini adalah keseluruhan responden penelitian siswa sebanyak 95 orang siswa yang terdiri dari empat kelas. Instrumen yang digunakan pada penelitian ini adalah tes kemampuan menyimpulkan. Untuk mengetahui kategori kemampuan menyimpulkan isi berita dan mengacu pada standar ketuntasan belajar individual dan klasikal yang digunakan di SMP Negeri I Barangka. Hasil penelitian menunjukkan bahwa dari 95 orang siswa yang menjadi seluruh responden penelitian, secara individual terdapat 84 orang siswa $(88,42 \%)$ masuk kategori mampu dan 11 orang siswa $(11,57 \%)$ masuk kategori tidak mampu dalam menyimpulkan isi berita. Secara klasikal, kemampuan menyimpulkan isi berita kelas VIII SMP Negeri I Barangka masuk kategori mampu. Dikatakan mampu karena kemampuan siswa mencapai 88,42\% telah mencapai kriteria ketuntasan klasikal yaitu mencapai 85\%. Dilihat dari tingkat kemampuan siswa kelas VIII SMP Negeri I Barangka pada setiap unsur dapat disimpulkan bahwa dari keenam komponen yang menjadi unsur penilaian yakni pada unsurapa, kapan, mengapa dan bagaimana tidak tuntas secara klasikal sedangkan unsursiapa, dan dimana tuntas secara klasikal karena persentasenya telah mencapai kriteria ketuntasan klasikal $85 \%$.
\end{abstract}

Kata Kunci : kemampuan, menyimak, berita 


\section{PENDAHULUAN}

\subsection{Latar Belakang}

Sesuai dengan kodratnya, manusia sebagai makhluk sosial akan selalu membutuhkan kehadiran manusia lain dalam kehdupannya. Hal ini akan mendorong manusia untuk hidup berkelompok dan saling berinteraksi satu sama lain. Dalam hubungan interaksi inilah, bahasa mengambil peran yang paling sentral sebagai alat komunikasi atau penghubung antar individu dalam sebuah kelompok atau antarakelompok yang satu dengan kelompok yang lainnya.

Hubungan interaksi antara manusia dalam kehidupannya tidak hanya terjadi melalui komunikasi secara lisan, tetapi juga menggunakan tulisan. Untuk itu, kita mengenal adanya bahasa lisan dan juga bahasa tulis. Lahirnya bahasa tulis sebagai jawaban dari berbagai kelemahan yang terdapat dalam bahasa lisan, diantaranya keterbatasan manusia untuk dapat menyerap informasi yang disampaikan secara lisan serta adanya situasi-situasi tertentu yang mengharuskan komunikasi tidak selalu terjadi secara langsung, melainkan melalui sebuah media perantara, yakni bahasa tulis. Dengan demikian, bahasa tulis memegang peranan penting dalam kehidupan sehari-hari.

Dalam dunia pendidikan, pembelajaran bahasa Indonesia pada setiap jenjang pendidikan mulai dari sekolah dasar, sekolah menengah, hingga perguruan tinggi selalu ditujukan pada penguasaan empat keterampilan berbahasa. Keterampilan yang harus dikuasai oleh setiap peserta didik tersebut meliputi keterampilan menyimpulkan, keterampilan berbicara, keterampilan membaca, dan keterampilan menulis. Dalam proses pembelajaran, guru akan selalu berusaha untuk mengembangkan empat keterampilan tersebut sehingga peserta didik diharapkan dapat menyimak secara terampil, berbicara secara terampil, membaca secara terampil, dan menulis secara terampil.
Salah satu pembelajaran yang terdapat dalam Kurikulum 2013 pada tingkat Sekolah Menengah Pertama (SMP) adalah keterampilan dalam menyimpulkan isi berita. Menyimpulkan isi berita merupakan salah satu materi yang tercantum dalam Kurikulum 2013 yang dijabarkan dalam kompetensi dasar (KD) SMP kelas VIII Semester satu, khususnya KD. 4.1 "Menyimpulkan isi dari berita (membanggakan dan memotivasi) yang dibaca dan didengar" dengan Indikator Pencapaian Kompetensi "Menyimpulkan isi teks Berita". Indikator pencapaian hasil belajar dalam kemampuan menyimpulkan isi berita untuk kelas VIII SMP menuntut siswa agar mampu memahami isi berita yang dibaca atau yang didengar serta mampu menangkap unsur-unsur $(5 \mathrm{~W}+1 \mathrm{H})$ yang terdapat dalam berita tersebut lalu menuliskannya kembali dalam sebuah kesimpulan dengan bahasa sendiri.

Berdasarkan hasil observasi awal dengan guru mata pelajaran bahasa Indonesia SMP Negeri 1 Barangka Kabupaten Muna Barat dikatakan bahwa materi menyimpulkan isi berita memang salah satu materi yang telah diajarkan di sekolah kelas VIII pada semester satu dan telah diajarkan. Dalam proses pembelajaran, terlebih dahulu guru memberikan materi pembelajaran kepada siswa berupa materi dan contoh kesimpulan berita, kemudian dilanjutkan dengan latihan menyimpulkan berita yang dilakukan oleh siswa bersama-sama dengan guru. Namun, pada akhir proses pembelajaran guru tidak melanjutkan dengan kegiatan pemberian tes kepada siswa, yakni tes menyimpulkan isi berita sebagai bentuk evaluasi dari pembelajaran yang telah berlangsung.

\subsection{Rumusan Masalah}

Berdasarkan latar belakang yang telah dikemukakan tersebut, maka yang menjadi rumusan masalah dalam penelitian ini adalah bagaimanakah kemampuan menyimpulkan isi berita siswa kelas VIII 
SMP Negeri 1 Barangka Kabupaten Muna Barat?

\subsection{Tujuan Penelitian}

Tujuan penelitian ini adalah untuk mendeskripsikan kemampuan menyimpulkan isi berita siswa kelas VIII SMP Negeri 1 Barangka Kabupaten Muna Barat.

\subsection{Manfaat Penelitian}

Manfaat dalam penelitian ini adalah:

a. Sebagai bahan pertimbangan dan rujukan bagi sekolah selaku pembuat kebijakan terhadap program pembelajaran bahasa, khususnya menyimpulkan isi berita.

b. Bagi guru, penelitian ini dapat dijadikan sebagai bahan informasi bagi perencanaan pelaksanaan dan pengevaluasiaan pembelajaran selanjutnya khususnya pembelajaran menyimpulkan isi berita.

c. Bagi siswa, penelitian ini dapat dijadikan sebagai sumbangan pemikiran dalam meningkatkan pemahamannya tentang menyimpulkan isi berita.

d. Bagi peneliti, Sebagai bahan informasi tambahan bagi peneliti dan penelitipeneliti selanjutnya untuk dijadikan rujukan penelitian yang relevan.

\subsection{Batasan Operasional}

Batasan operasional dalam penelitian ini adalah sebagai berikut:

1. Kemampuan yang dimaksud dalam penelitian ini adalah kesanggupan atau kecakapan yang dimiliki oleh siswa kelas VIII SMP Negeri 1 Barangka dalam menyimpulkan isi berita.

2. Menyimpulkan yaitu menetapkan, menyarikan, atau mengambil inti atau pokok-pokok yang diuraikan dalam sebuah tulisan.

3. Berita adalah sebagai keterangan mengenai kejadian atau peristiwa yang hangat. Hangat berarti sesuatu yang baru saja terjadi dan penting untuk diketahui oleh khalayak.
4. Kemampuan menyimpulkan isi berita adalah kemampuan siswa untuk memahami isi berita yang dibaca atau yang di dengar serta mampu menangkap unsur-unsur $(5 \mathrm{~W}+1 \mathrm{H})$ yang terdapat dalam berita tersebut lalu menuliskannya kembali dalam sebuah kesimpulan dengan bahasa sendiri.

\section{Kajian Pustaka}

\subsection{Pengertian Menyimpulkan}

Dalam Kamus Besar Bahasa Indonesia (KBBI), menyimpulkan berarti menetapkan, menyarikan pendapat dan sebagainya berdasarkan apa yang diuraikan dalam karangan (pidato dan sebagainya). Proses menyimpulkan akan menghasilkan sebuah kesimpulan. Kesimpula sendiri dalam KBBI merupakan pendapat terakhir yang dibuat berdasarkan uraian sebelumnya.

Rakhman (2010:29) mengatakan bahwa menyimpulkan adalah mengambil inti atau pokok-pokok yang diuraikan dalam karangan. Agar dapat menyimpulkan bacaan, kita harus mengetahui dahulu teknik-tekniknya. Teknik yang dimaksud adalah (a) membaca bacaan berulang-ulang dengan seksama; (b) mengambil inti-inti atau pokok-pokok masalah yang sering muncul dalam bacaan tersebut; serta (c) menulis atau menyusun kembali inti/pokok bacaan tersebut secara runtut. Menyimpulkan dapat dilakukan dengan dua cara, yaitu secara dedukatif dan indukatif. Menyimpulkan secara dedukatif ialah cara mengambil simpulan dari pernyataan yang bersifat umum diikuti oleh uraian atau pernyataan-pernyataan yang bersifat khusus. Sedangkan menyimpulkan secara indukatif ialah cara mengambil simpulan dari pernyataan-pernyataan atau faktafakta yang bersifat khusus menuju ke suatu simpulan yang bersifat umum.

Lebih lanjut, Rakhman (2010:29) mengatakan bahwa menyampaikan simpulan dapat dilakukan secara lisan maupun tulisan. Selain memuat inti-inti 
atau pokok karangan, penyampaian kesimpulan juga harus menggunakan bahasa Indonesia yang baik dan benar. Simpulan yang disampaikan dapat diperoleh dari informasi lisan maupun maupun tulisan, baik informasi lisan yang bersifat verbal maupun informasi tulisan yang berbentuk nonverbal. Simpulan dapat disertakan dengan opini atau pendapat. Opini adalah pandangan berdasarkan ideologi atau sikap seseorang dalam memberikan suatu wawasan terhadap objek atau peristiwa. opini dapat juga disebut pendapat sesorang. Antonim dari opini adalah fakta. Fakta bersifat objektif, merupakan kenyataan bersifat kongkret dan dapat dibuktikan kebenarannya.

Menyimpulkan bacaan adalah menyarikan apa yang telah dibaca. Bacaan yang dimaksud dalam penelitian ini adalah teks berita. Proses menyimpulkan membutuhkan pemahaman yang baik. Wainwright dalamPurwanitaninggrum, dkk (2013:3) mengatakan bahwa pemahaman bacaan merupakan proses kompleks yang melibatkan pemanfaatan berbagai kemampuan. Dengan kata lain, keterampilan menyimpulkan merupakan kegiatan meresum atau meringkas beberapa pernyataan yang terdapat dalam sebuah bacaan. Keterampilan menyimpulkan menuntut pembaca untuk mampu menguraikan berbagai aspek scara bertahap agar sampai pada tahap sebuah formula baru, yakni sebuah kesimpulan.

Berdasarkan beberapa pendapat yang telah dikemukakan di atas, dapat ditarik kesimpulan bahwa proses menyimpulkan adalah proses menyarikan atau membuat resume tentang ide-ide atau pokok-pokok yang terdapat dalam sebuah bacaan menjadi sebuah pernyataan baru yang disebut kesimpulan.

\subsection{Pengertian Menulis}

Menurut Sumarjo Dalam Komaidi (2017:15), menulis adalah suatu proses melahirkan tulisan yang berisi gagasan. Proses menulis dapat dilakukan secara spontan, tetapi juga ada yang berkali-kali mengadakan koreksi dan penulisan kembali. Sebuah tulisan dapat diselesaikan dalam waktu singkat, maupun membuthkan waktu berhari-hari bergantung pada potensi dan kreatifitas setiap orang yang pada dasarnya berbedabeda.

Marwoto dalam Dalman (2016:4) mengatakan bahwa menulis adalah mengungkapkan ide atau gagasannya dalam bentuk karangan secara leluasa. Dalam hal ini, menulis itu membutuhkan skemata yang luas sehingga si penulis mampu menuangkan ide, gagasan, pendapatnya dengan mudah dan lancar. Skemata itu sendiri adalah pengetahuan dan pengalaman yang dimiliki. Jadi, semakin schemata seseorang, semakin mudahlah ia menulis.

Menurut Tarigan dalam Dalman (2016:4) mengemukakan bahwa menulis adalah menurunkan atau melukiskan lambang-lambang grafik yang menghasilkan suatu bahasa yang dipahami oleh seseorang sehingga orang lain dapat membaca lambang-lambang grafik tersebut dan dapat memahami bahasa dan grafis itu. Mereka pun dapat mengerti tujuan pesan yang disampaikan.

Menurut McCrimmon dalam Sanddhono dan Slamet (2014:150), menulis adalah kegiatan menggali pikiran dan perasaan mengenai sesuatu objek, memiliki hal-hal yang akan ditulis, menentukan cara menuliskannya sehingga pembaca dapat memahami dengan mudah dan jelas. Pada dasarnya menulis itu, bukan hanya berupa berupa melahirkan pikiran atau perasaan, melainkan juga merupakan pengungkapan ide, pengetahuan, ilmu, dan pengalaman hidup seseorang dalam bahasa tulis. Oleh karena itu, menulis bukanlah merupakan kegiatan yang sederhana dan tidak perlu dipelajari, tetapi justru dikuasai.

Dari pendapat para ahli di atas, dapat disimpulkan bahwa menulis merupakan salah satu keterampilan berbahasa yang digunakan untuk mengungkapkan pikiran atau gagasan dan

\section{8 |Jurnal BASTRA (Bahasa dan Sastra), Vol. 4 No. 2, Edisi April 2019/e-ISSN: 2503-3875/ http://ojs.uho.ac.id/index.php/BASTRA}


untuk menyampaikan pesan (komunikasi) melalui bahasa tulis sebagai alat atau medianya, sehingga mudah untuk dipahami oleh pembaca.

\subsection{Hakikat Berita}

\subsubsection{Pengertian Berita}

Menurut Charnley dalam Komaidi (2017:96) mengatakan bahwa berita adalah laporan tercepat dari suatu peristiwa atau kejadian yang faktual, penting dan menarik bagi sebagian pembaca serta menyangkut kepentingan mereka.

Bleyer dalam Mu'takif (2011:11) mengatakan bahwa berita adalah segala sesuatu yang terkait waktu dan menarik perhatian banyak orang dan berita terbaik adalah hal-hal yang paling menarik yang menarik sebanyak mungkin orang (untuk membacanya).

Eriyanto (2011:32) mengatakan bahwa berita adalah cermin atau refleksi dari kenyataan. Oleh karena itu, berita haruslah sama dan sebangun dengan fakta yang hendak diliput.

Assegaff dalam Sudarman (2008:76) mengatakan bahwa berita adalah laporan tentang fakta atau ide yang termasa (terkini) yang dipilih oleh staf redaksi suatu harian untuk disiarkan, yang dapat menarik perhatian pembaca, entah karena luar biasa, entah karena penting atau akibatnya, entah pula karena dia mencakup segi-segi human interest seperti humor, emosi, dan ketegangan.

Dari beberapa pandangan para ahli di atas, dapat disimpulkan bahwa berita adalah laporan yang bersifat aktual tentang sebuah peristiwa tertentu, yang berisi fakta atau hal baru, serta manarik dan penting untuk diketahui oleh orang banyak.

\subsubsection{Jenis-Jenis Berita}

Mu'takif (2011:109-110) menyatakan bahwa secara garis besar berita dapat digolongkan menjadi 6 jenis yaitu:

1. Berita Langsung

Berita langsung adalah laporan peristiwa yang ditulis secara singkat, padat, tegas dan apa adanya. Berita langsung ditulis dengan gaya memaparkan peristiwa dalam keadaan apa adanya tanpa ditambah dengan penjelasan apalagi interpretasi. Berita langsung terdiri dari dua jenis: (a) berita keras (hard news), yaitu laporan peristiwa besar atau sangat menggemparkan memiliki lebih dari segi aktualitasnya: (b) berita lembut (soft news), yaitu berita pendukung dari informasi peristiwa atau gagasan yang sederhana.

2. Opini

Opini merupakan berita yang berisi pendapat, penyataan atau gagasan seseorang ahli atau pejabat mengenai suatu masalah atau peristiwa.

3. Berita Intepretatif

Berita imperatif adalah berita yang dikembangkan dalam komentar atau penilaian wartawan atau narasumber yang kompeten atas berita yang muncul sebelumnya, sehingga gabungan antara fakta dan interpretasi. Biasa berawal dari informasi yang dirasakan kurang jelas atau tidak lengkap artinya dan maksudnya.

4. Berita Mendalam

Berita mendalam adalah berita yang merupakan pengembangan dari berita yang suda muncul dengan pendalaman hal-hal yang ada dibawah suatun permukaan. Bermula dari sebuah berita yang masih belum selesai pengungkapannya dan bisa dilanjutkan kembali.

5. Berita Penjelasan

Berita penjelasan adalah berita yang sifatnya menjelaskan dengan menguraikan sebuah peristiwa secara lengkap, penuh data dan fakta yang diperoleh dijelaskan secara rinci dengan beberapa argumentasi atau pendapat penulisnya.

6. Berita penyelidikan

Berita penyelidikan adalah berita yang diperoleh dan dikembangkan berdasarkan penelitian atau penyelidikan dari berbagai sumber. Disebut pula berita penggalian karena 
wartawan mengambil informasi dari berbagai sumber, dengan melakukan penyelidikan langsung kelapangan.

\subsubsection{Unsur-Unsur Berita}

Junaedi (2015:11-13) mengatakan bahwa untuk memahami jurnalisme, maka perlu mengetahui unsur berita yang dikenal dengan rumus $5 \mathrm{~W}+1 \mathrm{H}$. Unsurunsur tersebut dijabarkan sebagai berikut:

1. Apa (What)

Apa berarti apa yang terjadi/akan terjadi. Ini berkaitan dengan apa yang diberitakan. Dalam jurnalisme, apa menunjukan tema apa yang diangkat dalam berita. Maka kita harus melihat kelayakan berita sebagaimana yang telah dijelaskan sebelumnya. Sebagai contoh: kalimat berita berikut ini, "Mahasiswa melakukan unjuk rasa menuntut penurunan menteri yang terlibat korupsi." Kalimat berita ini menunjukan yang terjadi yaitu peristiwa unjuk rasa.

2. Siapa (Who)

Siapa berarti kepada siapa suatu peristiwa terjadi, atau siapa yang melakukan atau terlibat dalam peristiwa tersebut. Siapa harus berkaitan dengan apa sehingga mampu memberikan informasi yang cukup kepada khalayak sekaligus dapat mendekatkan berita dengan khalayak. Contoh kalimat berita: "Mahasiswa melakukan unjuk rasa menuntuk penurunan menteri yang terlibat korupsi." Siapa dalam peristiwa ini adalah mahasiswa dan menteri yang terlibat korupsi. Unsur siapa ini dapat dijelaskan dan diperdalam dengan memberikan keterangan tentang siapa, seperti mahasiswa tersebut berasal dari kampus apa serta nama menteri yang terlibat dalam korupsi, berasal dari kementerian apa menteri tersebut, dan kasus korupsi apa yang membelitnya. Jadi, siapa bisa mencakup nama alamat, asal gelar dan sebagainya yang memperkaya informasi.
3. Kapan (When)

Unsur kapan memberikan informasi tentang kapan peristiwa tersebut terjadi. Jika tidak ada unsur lain, khalayak akan kebingungan kapan peristiwa yang diberitakan terjadi, apakah sedang terjadi saat diberitakan, kemarin, seminggu yang lalu, sebulan yang lalu atau bahkan setahun yang lalu. Kalimat berita yang dicontohkan di atas dapat dilanjutkan dengan kalimat, "Unjuk rasa terjadi siang tadi pukul 12.00 WIB."

4. Dimana (Where)

Dimana menunjukan dimana peristiwa yang diberitakan terjadi. Jika kita membaca kalimat berita, "Mahasiswa melakukan unjuk rasa menuntut penurunan menteri yang terlibat korupsi." Pada kalimat tersebut, kita belum menemukan informasi yang mencukupi tentang dimana peristiwa tersebut terjadi. Bisa jadi yang diberitakan terjadi dilingkungan lokal, nasional, maupun internasional. Dengan demikian, dalam berita perlu ada unsur dimana yang memberikan informasi tentang lokasi peristiwa yang diberitakan. Sebagai contoh: kalimat berita,"Mahasiswa melakukan unjuk rasa menuntut penurunan menteri yang terlibat korupsi." Agar unsur dimana terpenuhi, bisa ditambah dengan kalimat selanjutnya, "Unjuk rasa terjadi di depan Istana Negara, Jakarta."

5. Mengapa (Why)

Mengapa memberikan keterangan tentang mengapa peristiwa tersebut terjadi. Disini pembuat berita dituntut kemampuannya untuk mampu menggali informasi mengapa peristiwa terjadi kemudian menjadikannya sebuah berita. Sebagai contoh: kalimat berita "Mahasiswa melakukan unjuk rasa menuntut penurunan menteri yang terlibat korupsi." Kalimat tersebut bisa dilanjutkan dengan kalimat, "Unjuk rasa terjadi setelah presiden bersikukuh 
tidak memecat menteri yang terlibat melakukan korupsi."

6. Bagaimana (How)

Bagaimana menjelaskan bagaimana peristiwa yang diberitakan terjadi. Sebagai contoh: kalimat berita "Mahasiswa melakukan unjuk rasa menuntut penurunan menteri yang terlibat korupsi." Kalimat tersebut bisa ditambahkan kalimat selanjutnya untuk menjelaskan tentang bagaimanaunjuk rasa terjadi sebagai berikut, "Unjuk rasa mahasiswa ini berakhir rusuh setelah polisi membubarkan paksa aksi unjuk rasa dengan menembakkan gas air mata."

\subsubsection{Bagian-Bagian Berita}

1. Judul Berita

Judul berita merupakan gambaran topik berita yang berfungsi memberitahukan tentang berita yang akan disajikan dan berperan penting unutk menggiring pembaca agar menelusuri isi berita yang akan disampaikan untuk menarik perhatian pembaca dan menyimpulkan isi berita. Keterampilan yang diperlukan dalam menulis judul berita antara lain presepsi yang tepat mengenai berita, perbendaharaan kata yang luas dan pemahaman tajam tentang struktur kalimat agar baik dan menarik pembuatan judul berita dan harus memenuhi ketentuan sebagai berikut:

a. Diambil dari informasi di dekat bagian atas berita, bagian yang terpenting berita.

b. Dipilih kata-kata yang menarik biasanya diperkuat dengan huruf-huruf tebal, warna, dan menggunakan garis.

c. Biasanya kata benda diikuti kata kerja, atau teridiri atas subjek dan predikat.

d. Hampir selalu ditulis dalam kalimat kejadian sekarang, hindari kata telah, sudah, dan akan.

e. Nama seseorang digunakan jika dia tokoh.

f. Hanya digunakan tanta kutip tunggal.

g. Menghindari penggunaan singkat dan tanda Tanya.
2. Teras Berita

Teras berita atau yang lebih dikenal dengan istilah lead adalah bagian awal berita. Fakta-fakta terpenting pada terdapat pada paragraph pertama sampai pada paragraph kedua. Teras berita yang baik memuat semua komponen $(5 \mathrm{~W}+1 \mathrm{H}) \quad$ sehingga pembaca yang terburu-buru akan merasa cukup hanya membaca judul dan teras berita. Beberapa macam teras berita atau lead antara lain sebagai berikut.

a. Lead Ringkasan

Lead model ini banyak dipakai dalam penulisan straight news, yaitu menuliskan intisari cerita/peristiwa. Lead ini mudah ditulis, sehingga bila penulis kehabisan kreativitas mereka akan memilih model ini.

b. Lead Naratif

Model ini banyak disukai oleh para penulis fiksi. Penulis berusaha menarik minat membaca, melibatkan emosi pembaca ke dalamnya. Teknik menulis lead naratif adalah menciptakan suatu suasana dan membiarkan pembaca mengidentifikasi diri dengan tokoh utama. Keuntungan lead ini adalah bisa menarik pembaca lebih efektif dari pada lead model lain.

c. Lead Deskriptif

Lead deskriptif berusaha menggambarkan tokoh atau tempat kejadian dalam pikiran pembaca. Jika lead naratif meletakan pembaca di dalam cerita, maka lead deskriptif meletakan pembaca beberapa meter di depan sebuah tempat atau peristiwa dan berfungsi sebagai orang yang menonton, mendengar, atau mencium baunya.

d. Lead kutipan

Kutipan yang dalam dan ringkas bias menarik, terutama bila berasal dari ucapan orang terkenal. Perlu di ingat bahwa kutipan ini tidak boleh hanya menjadi sekedar tempelan tetapi harus menyiapkan pentas bagi babak selanjutnya bagi tulisan kita. 
3. Tubuh Berita

Tubuh berita merupakan keseluruhan dari peristiwa yang diangkat menjadi berita dan merupakan penerusan dan penjabaran lebih lanjut isi teras berita. Penjelasan itu meliputi penjelasan kelengkapan peristiwa yang diberitakan dan dianggap perlu diuaraikan kembali untuk member keterangan pada berita yang sudah disinggung pada teras berita. Tubuh berita dapat disusun dengan susunan piramida yang terbalik maksudnya, ditulis dari keterangan lanjut yang dianggap penting sampai yang kurang penting. Disusun dengan susunan kronologis maupun dengan susunan dimana informasi penting diletakkan di belakang. Di samping itu, kekuatan tubuh berita dapat pula dibangun dengan menyertakan kutipan, baik langsung maupun tidak langsung dari sumber berita; menyertakan nama/jabatan sumber berita (attribution); memberikan identifikasi yang jelas tentang siapa sumber berita serta menyertakan latar belakang berita.

\subsubsection{Nilai-Nilai Berita}

Menurut Mu'takif (2011: 16) mengatakan bahwa nilai berita adalah seperangkat kriteria untuk menilai apakah sebuah kejadian cukup penting untuk diliput. Ada sejumlah faktor yang membuat sebuah kejadian memiliki nilai berita. Tujuh diantaranya adalah sebagai berikut:

1. Kedekatan (Proximity)

Kedekatan dapat dibedakan menjadi dua, yakni kedekatan secara fisik dan kedua kedekatan secara emosional. Orang cenderung tertarik bila membaca berita yang peristiwa atau kejadiannya dekat dengan wilayahnya dan juga perasaan emosional berdasarkan ikatan tertentu.

2. Ketenaran (Prominince)

Orang terkenal memang sering menjadi bahan pemberitaan Seperti kata ungkapan Barat, Name makes news. Bintang film, sinetron, bintang sepakbola, politisi ternama seringkali muncul dalam pemberitaan baik di media cetak maupun elektronik.

3. Aktualitas (Time Liness)

Berita, khususnya straight news haruslah berupa laporan kejadian yang baru-baru ini terjadi atau peristiwaperistiwa yang akan terjadi di masa depan.

4. Dampak (Impact)

Sebuah kejadian yang memiliki dampak pada masyarakat luas memiliki nilai berita yang tinggi. Semakin besar dampak tersebut bagi masyarakat, semakin tinggi pula nilai beritanya.

5. Keluarbiasaan (Magnitude)

Sebenarnya hampir sama dengan dampak, Namun keluarbiasaan di sini menyangkut sejumlah orang besar, prestasi besar, kehancuran yang besar, kemenangan besar, dan segala sesuatu yang besar.

6. Konflik (Conflict)

Konflik berita tentang adanya bentrokan, baik secara fisik maupun nonfisik selalu menarik. Misalnya, bentrokan antarmanusia, manusia dengan binatang, antarkelompok, bangsa, etnik, agama, kepercayaan, perang dan sebagainya.

7. Keanehan (Oddity)

Sesuatu yang tidak lazim (unusual) mengundang perhatian orang di sekitarnya. Orang yang bergaya hidup yang tidak biasa memiliki ukuran fisik yang berbeda dengan yang lain pada umumnya dan sebagainya cenderung masuk dalam pemberitaan yang bernilai tinggi.

\subsubsection{Surat Kabar Sebagai Media Penyalur Berita \\ Mu'takif (2011:121) mengatakan} bahwa surat kabar merupakan media penyampai pesan yang mempunyai daya jangkau luas dan masal. Pada sejarahnya, McQuail \& Baran dalam Atmaja dan Ariyani (2018:102) mengatakan bahwa 
surat kabar muncul pertama kali adalah Corantos yang terbit di Belanda pada abad ke-18 dengan menggunakan bahasa Inggris. Surat kabar terus berkembang kearah surat kabar modern pada abad ke19 di kota New York yang bernama New York Sun. Mu'takif mengatakan bahwa dalam penyebarluasan media, surat kabar memiliki kelebihan dibanding dengan jenis media lain, yakni:

1. Market coverage tinggi, yaitu mampu sampai kepelosok daerah serta mempunyai distribusi yang fleksibel.

2. Harga relatif murah hingga mampu dikonsumsi oleh segalah lapisan masyarakat.

3. Comparison Shopping (catalogue product). Kebiasaan orang sebelum berbelanja selalu memperhatikan koran sebagai referensi.

4. Surat kabar memiliki karakter yang kuat karena memiliki berita-berita yang aktual sesuai dengan perkembangan pemikiran masyarakat yang semakin dewasa.

5. Surat kabar mempunyai target pasar sendiri sesuai dengan target khalayak pembacanya.

6. Surat kabar dapat dibeli tanpa harus menjadi pelanggan/eceran.

7. Ada ruang beriklan/space yang khusus buat produk.

8. Fleksibel ketika menjadi bagian dari iklan produk.

Selanjutnya, McQuail dalam Atmaja dan Ariyani (2018:102) mengatakan bahwa surat kabar memiliki beberapa ciri, yakni: pertama, kemunculannya berkala dan sering. Kedua, menggunakan teknologi percetakan. Ketiga, isi dan rujukan menurut tema tertentu. Keempat, dibaca oleh individu atau kelompok.

\subsection{Pembelajaran Menyimpulkan Isi Berita di SMP}

Berdasarkan observasi awal yang telah dilakukan, dapat diketahui bahwa pembelajaran menyimpulkan isi teks berita telah dipelajari di kelas VIII pada semester 1 (satu). Pembelajaran menyimpulkan isi berita tersebut mengacu pada Kurikulum 2013 yang diterbitkan oleh Depdiknas. Dalam penelitian ini, difokuskan pada menyimpulakan isi teks berita sebagai objek penelitian. Pembelajaran menyimpulkan isi teks berita dalam Kurikulum 2013 di kelas VIII dipelajari pada semester 1 dengan kompetensi dasar, yakni menyimpulkan isi dari berita (membanggakan dan memotivasi) yang dibaca dan didengar dengan salah satu indikator pencapaian kompetensi, yaitu menyimpulkan isi teks berita.

Kemampuan menyimpulkan isi berita diajarkan kepada siswa dengan tujuan agar siswa mampu menyimpulkan isi teks berita dengan mencakup keseluruhan unsur yang terdapat dalam berita serta menggunakan bahasa yang baik dan benar. Pembelajaran menyimpulkan isi berita dilaksanakan sebanyak satu kali pertemuan atau dua jam pelajaran ( 2 x 40 menit). Adapun aspekaspek yang dinilai dalam menyimpulkan isi berita adalah isi kesimpulan berita yang meliputi unsur $5 \mathrm{~W}+1 \mathrm{H}$ yang ditulis dalam satu bentuk paragraf dengan memperhatikan aturan penulisan berdasarkan ejaan yang benar dan menggunakan kalimat yang mudah dipahami.

Materi ajar tentang menyimpulkan isi berita yang digunakan oleh guru dalam proses pembelajaran bersumber buku siswa dan buku guru mata pelajaran Bahasa Indonesia kelas VIII Kurikulum 2013 edisi revisi 2017 terbitan Kementerian Pendidikan dan Kebudayaan Republik Indonesia.

Materi ajar tentang menyimpulkan isi berita terdapat pada bab 1 "Berita Seputar Indonesia" subbab bagian B, yakni "Meringkas dan Menyimpulkan Isi Berita". Rangkuman materi ajar tentang menyimpulkan isi berita secara garis besar adalah sebagai berikut:

1. Pengertian kesimpulan berita.

Kesimpulan berita adalah kata-kata akhir dari sebuah uraian atau teks 
berita yang harus memuat unsur-unsur berita dengan rumusan lebih ringkas.

2. Langkah-langkah menyimpulkan isi teks berita, yakni sebagai berikut:

a. Membaca dengan seksama berita yang disajikan.

b. Menentukan unsur-unsur berita yang dibaca. Unsur-unsur yang dimaksud adalah apa, siapa, di mana, kapan, mengapa, dan bagaimana.

c. Setelah menentukan unsur-unsur berita yang telah dibaca, langkah selanjutnya adalah merangkai seluruh unsur-unsur tersebut menjadi sebuah kesimpulan dengan redaksi kalimat sendiri.

d. Kesimpulan isi berita yang dibuat haruslah dalam bentuk paragraf singkat (satu paragraf).

3. Disajikan beberapa contoh kesimpulan berita untuk dibaca dan dipahami oleh siswa.

4. Mengerjakan latihan-latihan tentang menyimpulkan isi teks sebuah berita (disajikan sebuah teks berita, kemudian siswa membuat kesimpulan berita tersebut).

\section{METODE DAN TEKNIK PENELITIAN}

\subsection{Jenis dan Metode Penelitian}

\subsubsection{Jenis Penelitian}

Penelitian ini berdasarkan pada jenisnya merupakan penelitian kelas, karena peneliti turun ke sekolah tempat penelitian untuk mengumpulkan data sesuai dengan masalah dalam penelitian ini, yakni SMP Negeri 1 Barangka, Kabupaten Muna Barat.

\subsubsection{Metode Penelitian}

Metode yang digunakan dalam penelitian ini adalah metode deskriptif kuantitatif. Deskriptif yaitu mendeskripsikan data penelitian secara objektif tentang kemampuan menyimpulkan isi berita siswa kelas VIII SMP Negeri 1 Barangka Kabupaten Muna Barat. Kuantitatif maksudnya adalah data yang terkumpul merupakan hasil pengukuran dan diolah dengan menggunakan rumus statistik.

\subsection{Populasi dan Sampel Penelitian \\ 3.2.1 Populasi Penelitian}

Menurut Sugiyono (2015: 117), populasi adalah wilayah generalisasi yang terdiri atas: obyek/subyek yang mempunyai kualitas dan karakteristik tertentu yang ditetapkan oleh peneliti untuk dipelajari dan kemudian ditarik kesimpulannya. Populasi dalam penelitian ini adalah keseluruhan siswa kelas VIII SMP N 1 Barangka Kabupaten Muna Barat tahun pelajaran 2018/2019 yang berjumlah 125 orang yang terdiri dari lima kelas, dengan rincian kelas VIII $^{1} 24$ siswa, VIII $^{2} 24$ siswa, VIII ${ }^{3} 27$ siswa, VIII ${ }^{4} 24$ siswa, VIII ${ }^{5} 26$ siswa

Untuk lebih jelasnya, keadaan populasi dapat dilihat pada tabel berikut ini:

Tabel Sebaran Populasi Kelas VIII SMP Negeri 1 BarangkaT.P. 2018/2019

\begin{tabular}{|l|c|c|}
\hline No. & Kelas & $\begin{array}{c}\text { Jumlah } \\
\text { Siswa }\end{array}$ \\
\hline 1 & VIII $^{1}$ & 24 siswa \\
\hline 2 & VIII $^{2}$ & 24 siswa \\
\hline 3 & VIII $^{3}$ & 27 siswa \\
\hline 4 & VIII $^{4}$ & 24 siswa \\
\hline 5 & VIII $^{5}$ & 26 siswa \\
\hline \multicolumn{2}{|l|}{ Jumlah Keseluruhan } & $\mathbf{1 2 5}$ siswa \\
\hline
\end{tabular}

\subsubsection{Sampel Penelitian}

Teknik yang digunakan dalam pengambilan sampel pada penelitian ini adalah Stratified proporsional random sampling yakni pengambilan sampel dengan cara merangking prestasi siswa dari yang terendah sampai yang tertinggi berdasarkan nilai ujian semester 2 (dua) kelas VII. Teknik ini digunakan bila populasi mempunyai anggota/unsur yang tidak homogen dan berstrata secara proporsional. 


\subsection{Instrumen Penelitian}

Menimbang jumlah sampel penelitian yang tergolong besar, maka pelaksanaan tes dibagi menjadi empat kelas (A, B, C, D) yang setiap anggota kelas dipilih berdasarkan nomor urut siswa. Kelas A, B, C tediri atas 24 siswa dan kelas D 23 siswa. Hal ini bertujuan untuk menjaga kondisi kelas agar tetap terkendali dan siswa dapat bekerja dengan baik. Instrumen yang digunakan dalam penelitian ini adalah tes kemampuan menyimpulkan isi berita. Tes ini digunakan untuk mengukur kemampuan siswa dalam menyimpulkan isi berita. Selanjutnya, siswa diberikan teks berita yang bersumber dari surat kabar Kolaka Pos. Tes ini dilakukan dalam satu kali pertemuan selama 80 menit atau 2 x 40 menit ( 2 jam pelajaran).

\subsection{Teknik Pengumpulan Data}

Data yang diperoleh dari hasil tulisan siswa setelah terkumpul, diamati dan diolah sesuai dengan aspek-aspek yang diteliti. Adapun langkah-langkah yang dilakukan meliputi:

1. Mengumpulkan siswa dalam ruangan kelas.

2. Siswa menyiapkan alat-alat tulis yang mendukung kegiatan menulis.

3. Membagikan instrumen kepada siswa.

4. Memberikan kesempatan untuk bertanya tentang petunjuk instrumen.

5. Siswa mengerjakan tes yang diberikan yakni menyimpulkan isi teks berita berdasarkan istrumen yang telah dibagikan.

6. Setelah waktu yang diberikan selesai, lembar kerja siswa dikumpul.

7. Guru dan peneliti memeriksa lembar kerja siswa.

\subsection{Teknik Penilaian}

Untuk menilai hasil tulisan siswa, peneliti menggunakan teknik analitik, yaitu diarahkan pada ketepatan isi simpulan yang memuat unsur $5 \mathrm{~W}+1 \mathrm{H}$. Skala penelitian tersebut mengacu pada pedoman menyimpulkan isi berita yang ditetapkan oleh pusat penilaian pendidikan Departemen Pendidikan Nasional yang diterapkan di SMP Negeri 1 Barangka.

\subsection{Teknik Analisis Data}

Data-data yang terkumpul dari hasil penelitian, selanjutnya diolah dan ditabulasi berdasarkan klasifikasi skor masing-masing siswa. Selanjutnya, datadata yang ditemukan diuraikan secara deskriptif dengan menggunakan teknik persentase sesuai dengan prinsip statistik. Tingkat kemampuan menyimpulkan isi berita siswa mengacu pada kemampuan, yaitu suatu anggapan bahwa secara individual siswa dianggap mampu apabila memiliki penguasaan minimal $75 \%$ dari setiap aspek yang dinilai sesuai Kriteria Ketuntasan Minimal (KKM) dan secara klasikal siswa dianggap mampu apabila memiliki penguasaan minimal $85 \%$.

Untuk mengetahui kategori kemampuan menyimpulkan isi berita siswa kelas VIII SMP Negeri 1 Barangka Kabupaten Muna Barat digunakan rumus dengan membagi perolehan skor yang diperoleh siswa dengan jumlah keseluruhan skor (maksimum) dikali $100 \%$.

Rumus yang digunakan untuk menentukan persentase ketuntasan siswa secara individual adalah:

$$
\mathrm{Kl}=\frac{\text { jumlah skor yang diperoleh }}{\text { Jumlah skor maksimal }} \times 100 \%
$$

Keterangan:

$\mathrm{KI}=$ Ketuntasan Individual

Rumus yang dipakai untuk menentukan ketuntasan pembelajaran siswa secara klasikal adalah:

Rumus yang dipakai untuk menentukan ketuntasan pembelajaran siswa secara klasikal adalah:

KK

$$
=\frac{\text { jumlah yang memperoleh persentase } \geq 75}{\text { Jumlah sampel }} \times 100 \%
$$

Keterangan:

$\mathrm{KK}=$ Ketuntasan Klasikal

Dari persentase yang diperoleh, baik untuk kemampuan siswa secara individual maupun secara klasikal selanjutnya 
diacukan pada penilaian yang telah ditetapkan untuk menentukan kemampuan siswa. Untuk lebih jelasnya berikut adalah tabel penilaian kemampuan.

Tabel Kriteria Kategori Kemampuan

\begin{tabular}{|c|c|l|}
\hline Kategori & $\begin{array}{c}\text { Rentang } \\
\text { Skor }\end{array}$ & $\begin{array}{l}\text { Presentase } \\
\text { Kemampuan(\%) }\end{array}$ \\
\hline Mampu & $14-18$ & $77,78 \%-100 \%$ \\
\hline $\begin{array}{c}\text { Tidak } \\
\text { Mampu }\end{array}$ & $6-13$ & $33,33 \%-72,22 \%$ \\
\hline
\end{tabular}

Berdasarkan tabel tersebut, maka dapat dijelaskan sebagai berikut:

1. Siswa dikatakan mampu apabila mencapai skor $14-18$, dengan persentase $77,78 \%-100 \%$.

2. Siswa dikatakan tidak mampu apabila mencapai skor 6 - 13 dengan persentase $33,33 \%-72,22 \%$.

\section{HASIL PENELITIAN}

\subsection{Deskripsi Hasil Penelitian}

Kemampuan Menyimpulkan Isi Berita Siswa Kelas VIII SMP Negeri 1 Barangka

Gambaran tentang kemampuan menyimpulkan isi berita siswa kelas VIII secara keseluruhan SMP Negeri 1 Barangka disajikan melalui table berikut:

Tabel Kemampuan Menyimpulkan Isi Berita Siswa Kelas VIII SMP Negeri 1 Barangka

\begin{tabular}{|c|c|c|}
\hline Kategori & Frekuensi & $\begin{array}{c}\text { Persentase } \\
(\mathbf{\%})\end{array}$ \\
\hline Mampu & 84 & $88,42 \%$ \\
\hline $\begin{array}{c}\text { Tidak } \\
\text { Mampu }\end{array}$ & 11 & $11,57 \%$ \\
\hline Jumlah & $\mathbf{9 5}$ & $\mathbf{1 0 0}$ \\
\hline
\end{tabular}

Berdasarkan tabel datas dapat dilihat bahwa dari 95 orang yang menjadi responden penelitian terdapat 84 orang siswa $(88,42 \%)$ yang memperoleh kategori mampu dan 11 orang siswa memperoleh $(11,57 \%)$ masuk kategori tidak mampu. Dengan demikian, kemampuan menyimpulkan isi berita siswa kelas VIII SMP Negeri 1 Barangka dikategorikan mampu secara klasikal. Dikatakan mampu karena siswa yang mencapai kemampuan individual $\geq 75 \%$ mencapai $88,42 \%$ dan telah mencapai kriteria ketuntasan klasikal $85 \%$.

\subsection{Deskripsi Kemampuan}

Menyimpulkan Isi Berita Siswa Kelas

VIII SMP Negeri 1 Barangka

Kabupaten Muna Barat pada Setiap Unsur

Pada bagian ini akan disajikan hasil penelitian dengan persentase kemampuan menyimpulkan isi berita siswa kelas VIII SMP Negeri 1 Barangka Kabupaten Muna Barat pada setiap unsur, yaitu Apa, Dimana, Kapan Siapa, Mengapa, dan Bagaimana.

\subsubsection{Deskripsi Kemampuan}

\section{Menyimpulkan Isi Berita Siswa Kelas VIII SMP Negeri 1 \\ Barangka pada Unsur Apa}

Distribusi kemampuan menyimpulkan isi berita siswa kelas VIII SMP Negeri 1 Barangka Kabupaten Muna Barat pada unsur apa dapat dilihat pada table berikut:

\begin{tabular}{|c|c|c|l|}
\hline Skor & Frek. & $\mathbf{( \% )}$ & Kategori \\
\hline $\mathbf{3}$ & $\mathbf{6 8}$ & $\mathbf{7 1 , 5 7 \%}$ & Mampu \\
\hline 2 & $\mathbf{2 1}$ & $\mathbf{2 2 , 1 0 \%}$ & $\begin{array}{l}\text { Tidak } \\
\text { Mampu }\end{array}$ \\
\hline 1 & $\mathbf{6}$ & $\mathbf{6 , 3 1 \%}$ & $\begin{array}{l}\text { Tidak } \\
\text { Mampu }\end{array}$ \\
\hline Jum. & $\mathbf{9 5}$ & $\mathbf{1 0 0 \%}$ & - \\
\hline
\end{tabular}

Berdasarkan hasil pengolahan data tentang kemampuan menyimpulkan isi berita pada unsur apa menunjukan bahwa dari 95 orang siswa kelas VIII SMP Negeri 1 Barangka kabupaten Muna Barat sebanyak 68 orang siswa dengan presentasi $(71,57 \%)$ masuk kategori mampu sedangkan 27 orang siswa $(28,42 \%)$ masuk kategori tidak mampu. Dengan demikian, bila dilihat dari kemampuan menyimpulkan isi berita ditinjau dari unsur apa secara klasikal masuk kategori tidak mampu, karena kemampuan siswa mencapai $71,57 \%$ atau kurang dari kemampuan klasikal 85\%. 
4.2.2 Deskripsi Kemampuan

Menyimpulkann isi berita siswa kelas VIII SMP Negeri 1 Barangka Unsur Siapa

Distribusi kemampuan menyimpulkan isi berita siswa kelas VIII SMP Negeri 1 Barangka Kabupaten Muna Barat pada unsur siapa dapat dilihat pada table berikut:

\begin{tabular}{|c|c|l|l|}
\hline Skor & Frek. & $\mathbf{( \% )}$ & Kategori \\
\hline $\mathbf{3}$ & $\mathbf{9 5}$ & $\mathbf{1 0 0 \%}$ & Mampu \\
\hline $\mathbf{2}$ & - & - & Tidak Mampu \\
\hline $\mathbf{1}$ & - & - & Tidak Mampu \\
\hline Jum. & $\mathbf{9 5}$ & $\mathbf{1 0 0 \%}$ & - \\
\hline
\end{tabular}

Berdasarkan hasil pengolahan data tentang kemampuan menyimpulkan isi berita pada unsur siapa menunjukan bahwa dari 95 orang siswa kelas VIII SMP Negeri 1 Barangka, 95 orang siswa (100\%) yang secara individual dikategorikan mampu dan sebanyak 0 orang siswa $(0 \%)$ dikategorikan tidak mampu. Dengan demikian, bila dilihat dari kemampuan menyimpulkan isi berita ditinjau dari unsur siapa secara klasikal masuk kategori mampu, karena kemampuan siswa mencapai $100 \%$ atau lebih dari batas kemampuan secara klasikal $85 \%$

\subsubsection{Deskripsi Kemampuan}

Menyimpulkan Isi Berita siswa kelas VIII SMP Negeri 1 Barangka pada Unsur Kapan.

Distribusi kemampuan menyimpulkan isi berita siswa kelas VIII SMP Negeri 1 Barangka Kabupaten Muna Barat pada unsur kapan dapat dilihat pada table berikut:

\begin{tabular}{|c|c|c|l|}
\hline Skor & Frek. & $\mathbf{( \% )}$ & Kategori \\
\hline $\mathbf{3}$ & $\mathbf{7 9}$ & $\mathbf{8 3 , 1 5 \%}$ & Mampu \\
\hline 2 & 13 & $\mathbf{1 3 , 6 8 \%}$ & $\begin{array}{l}\text { Tidak } \\
\text { Mampu }\end{array}$ \\
\hline 1 & $\mathbf{3}$ & $\mathbf{3 , 1 6 \%}$ & $\begin{array}{l}\text { Tidak } \\
\text { Mampu }\end{array}$ \\
\hline Jum. & $\mathbf{9 5}$ & $\mathbf{1 0 0 \%}$ & - \\
\hline \multicolumn{4}{|c|}{ Berdasarkan hasil pengolahan data }
\end{tabular}

tentang kemampuan menyimpulkan isi berita pada unsur kapan menunjukan bahwa dari 95 orang siswa kelas VIII SMP
Negeri 1 Barangka, 79 orang siswa $(83,15 \%)$ yang secara individual dikategorikan mampu dan sebanyak 16 orang siswa $(16,84 \%)$ dikategorikan tidak mampu. Dengan demikian, bila dilihat dari kemampuan menyimpulkan isi berita ditinjau dari unsur kapan secara klasikal masuk kategori mampu, karena kemampuan siswa mencapai $83,15 \%$ atau mencapai kemampuan klasikal $85 \%$.

\subsubsection{Deskripsi Kemampuan}

Menyimpulkan Isi Berita siswa kelas VIII SMP Negeri 1 Barangka pada Unsur Dimana

Distribusi kemampuan menyimpulkan isi berita siswa kelas VIII SMP Negeri 1 Barangka Kabupaten Muna Barat pada unsur dimana dapat dilihat pada table berikut:

\begin{tabular}{|r|c|l|l|}
\hline Skor & Frek. & $\mathbf{( \% )}$ & Kategori \\
\hline $\mathbf{3}$ & $\mathbf{9 5}$ & $\mathbf{1 0 0 \%}$ & Mampu \\
\hline $\mathbf{2}$ & - & - & Tidak Mampu \\
\hline $\mathbf{1}$ & - & - & Tidak Mampu \\
\hline Jum. & $\mathbf{9 5}$ & $\mathbf{1 0 0 \%}$ & - \\
\hline
\end{tabular}

Berdasarkan hasil pengolahan data tentang kemampuan menyimpulkan isi berita pada unsur dimana menunjukan bahwa dari 95 orang siswa kelas VIII SMP Negeri 1 Barangka, 95 orang siswa (100\%) yang secara individual dikategorikan mampu dan sebanyak 0 orang siswa $(0 \%)$ dikategorikan tidak mampu. Dengan demikian, bila dilihat dari kemampuan menyimpulkan isi berita ditinjau dari unsur dimana secara klasikal masuk kategori mampu, karena kemampuan siswa mencapai $100 \%$ atau lebih dari batas kemampuan secara klasikal $85 \%$.

\subsubsection{Deskripsikan Kemampuan Menyimpulkan Isi Berita siswa kelas VIII SMP Negeri 1 Barangka pada Unsur Mengapa}

Distribusi kemampuan menyimpulkan isi berita siswa kelas VIII SMP Negeri 1 Barangka Kabupaten Muna Barat pada unsur mengapa dapat dilihat pada table berikut: 


\begin{tabular}{|r|c|l|l|}
\hline Skor & Frek. & $\mathbf{( \% )}$ & Kategori \\
\hline 3 & $\mathbf{4 2}$ & $\mathbf{4 4 , 2 1 \%}$ & Mampu \\
\hline $\mathbf{2}$ & $\mathbf{3 9}$ & $\mathbf{4 1 , 0 5 \%}$ & Tidak Mampu \\
\hline $\mathbf{1}$ & $\mathbf{1 4}$ & $\mathbf{1 4 , 7 4 \%}$ & Tidak Mampu \\
\hline Jum. & $\mathbf{9 5}$ & $\mathbf{1 0 0 \%}$ & - \\
\hline
\end{tabular}

Berdasarkan hasil pengolahan data tentang kemampuan menyimpulkan isi berita pada unsur mengapa menunjukan bahwa dari 95 orang siswa kelas VIII SMP Negeri 1 Barangka, 42 orang siswa $(44,21 \%)$ yang secara individual dikategorikan mampu dan sebanyak 53 orang siswa $(55,78 \%)$ dikategorikan tidak mampu. Dengan demikian, bila dilihat dari kemampuan menyimpulkan isi berita ditinjau dari unsur mengapa secara klasikal masuk kategori tidak mampu, karena kemampuan siswa 44,21\% atau kurang dari batas kemampuan klasikal $85 \%$.

\subsubsection{Deskripsi Kemampuan \\ Menyimpulkan Isi Berita siswa kelas VIII SMP Negeri pada Unsur Bagaimana}

Distribusi kemampuan menyimpulkan isi berita siswa kelas VIII SMP Negeri 1 Barangka Kabupaten Muna Barat pada unsur bagaimana dapat dilihat pada table berikut:

\begin{tabular}{|c|c|c|l|}
\hline Skor & Frek. & $\mathbf{( \% )}$ & Kategori \\
\hline $\mathbf{3}$ & $\mathbf{6 4}$ & $\mathbf{6 7 , 3 6 \%}$ & Mampu \\
\hline 2 & $\mathbf{2 0}$ & $\mathbf{2 1 , 0 5 \%}$ & $\begin{array}{l}\text { Tidak } \\
\text { Mampu }\end{array}$ \\
\hline 1 & $\mathbf{1 1}$ & $\mathbf{1 1 , 5 8 \%}$ & $\begin{array}{l}\text { Tidak } \\
\text { Mampu }\end{array}$ \\
\hline Jum. & $\mathbf{9 5}$ & $\mathbf{1 0 0 \%}$ & - \\
\hline
\end{tabular}

Berdasarkan hasil pengolahan data tentang kemampuan menyimpulkan isi berita pada unsur bagaimana menunjukan bahwa dari 95 orang siswa kelas VIII SMP Negeri 1 Barangka, 64 orang siswa $(67,36 \%)$ yang secara individual dikategorikan mampu dan sebanyak 31 orang siswa $(32,63 \%)$ dikategorikan tidak mampu. Dengan demikian, bila dilihat dari kemampuan menyimpulkan isi berita ditinjau dari unsur bagaimana secara klasikal masuk kategori tidak mampu, karena kemampuan siswa mencapai $67,36 \%$ atau kurang dari batas kemampuan klasikal $85 \%$.

\subsection{Interpretasi Hasil Penelitian}

Dari gambaran hasil penelitian di atas, dapat diinterpretasikan bahwa dari keenam komponen unsur penilaian, yaitu apa, dimana, kapan, siapa, mengapa, dan bagaimana, terdapat beberapa unsur masih kurang dipahami oleh siswa yakni unsur apa, mengapa dan bagaimana, sedangkan pada unsur dimana, kapan dan siapa dikategorikan mampu. Ketidakmampuan sebagian siswa disebabkan oleh beberapa hal, diantaranya sebagaimana telah dikemukakan pada bagian latar belakang penelitian yang mengatakan bahwa masih minimnya latihan-latihan atau pembiasaan yang diberikan oleh guru kepada siswa dalam hal menyimpulkan isi berita.

Sebagaimana telah disampaikan di atas, bahwa dari enam unsur berita yang ada, sebagian siswa masih terkendala pada tiga unsur, yakni apa, mengapa, dan bagaimana. Hal ini dapat dilihat pada hasil penelitian yang menunjukkan kemampuan siswa secara klasikal pada ketiga unsur tersebut masih dikategorikan tidak mampu. Hal ini disebabkan oleh beberapa faktor, diantaranya yakni ketidakmampuan siswa dalam menentukan pokok berita khususnya pada ketiga unsur berita tersebut yang menyebabkan siswa tidak mampu memahami isi berita secara utuh atau lengkap. Hal ini akan mempengaruhi kualitas kesimpulan berita yang ditulis oleh siswa karena dalam penelitian ini, baik dan tidaknya kesimpulan siswa sangat ditentukan oleh lengkap dan tidaknya pokok-pokok atau unsur berita yang dimuat dalam kesimpulan.

Selanjutnya, berdasarkan data hasil penelitian yang telah diolah dengan rumus statistik yang telah ditentukan sebelumnya, maka dapat dijelaskan bahwa secara klasikal kemampuan menyimpulkan isi berita siswa kelas VIII SMP Negeri 1 
Barangka masuk dalam kategori mampu karena kemampuan siswa mencapai $88,52 \%$ dan telah memenuhi standar ketuntasan klasikal, yakni $85 \%$. Dengan hasil ini, siswa harus lebih giat lagi dalam proses belajar mengajar, terutama untuk meningkatkan kemampuannya dalam hal menyimpulkan isi berita. Di samping itu, guru juga harus mengadakan kegiatan pembelajaran lebih baik lagi dan terus memberikan motivasi lebih intensif kepada siswa untuk terus belajar dan meningkatkan kemampunannya dalam rangka mencapai tujuan pembelajaran yang telah ditetapkan.

\section{PENUTUP}

\subsection{Kesimpulan}

Berdasarkan hasil penelitian dan analisis data yang dilakukan, dapat disimpulkan bahwa dari 95 orang siswa kelas VIII SMP Negeri 1 Barangka, secara individual terdapat 84 orang siswa $(88,52 \%)$ masuk kategori mampu dan 11 orang siswa $(11,57 \%)$ masuk kategori tidak mampu dalam menyimpulkan isi berita Secara klasikal. kemampuan menyimpulkan isi berita kelas VIII SMP Negeri 1 Barangka masuk kategori mampu, Dikatakan mampu karena kemampuan siswa sebesar $(88,52 \%)$ mencapai kriteria ketuntasan secara klasikal, yakni $85 \%$. Dilihat dari tingkat kemampuan siswa kelas VIII SMP Negeri 1 Barangka pada setiap unsur berita yang dinilai, dapat disimpulkan bahwa dari keenam unsur yang menjadi unsur penilaian yaitu pada unsur apa, siapa, kapan, dan dimana dikategorikan tuntas secara klasikal sedangkan unsur mengapa dan bagaimana tidak tuntas secara klasikal karena persentasenya tidak mencapai kriteria ketuntasan klasikal $85 \%$.

\subsection{Saran}

Dengan mengacu pada kemampuan siswa yang diperlihatkan dalam menyimpulkan isi berita dalam penelitian ini disarankan sebagai berikut.
1. Guru pendidikan bahasa indonesia perlu memberikan perhatian khusus kepada siswa yang belum memiliki kemampuan dalam menyimpulkan isi berita.

2. Untuk pembelajaran menyimpulkan isi berita, guru dapat menyesuaikan ketuntasan materi pembelajaran dengan pemahaman siswa sehingga keseluruhan unsur-unsur berita, yaitu apa, siapa, kapan, dimana, mengapa dan bagaimana dapat dimengerti oleh siswa.

3. Dalam proses belajar mengajar sebaiknya guru mata pelajaran Bahasa Indonesia perlu meningkatkan kemampuan para siswadengan sering memberikan latihan seperti menyimpulkan isi teks berita.

\section{DAFTAR PUSTAKA}

Atmaja, Nengah, Bawa, dan Luh Putu Sri Ariyanti. 2018. Sosiologi Media; Perspektif Teori Kritis. Depok: Rajawali Press.

Dalman. 2016. Keterampilan Menulis. Depok: PT. RajaGrafindo Persada.

Depdiknas. 2005. Kamus Besar Bahasa Indonesia Edisi Ketiga. Jakarta: Balai Pustaka.

Eriyanto. 2011. Analisis Wacana; Pengatar Analisis Teks Media. Yogyakarta: LKis.

Ishwara, Luwi. 2016. Jurnalisme Dasar. Jakarta: Kompas.

Junaedi, Fajar. 2015. Jurnalisme Penyiaran dan Reportase Televisi. Jakarta: Prenadamedia Group.

Komaidi, Didik. 2017. Panduan Lengkap Menulis Kreatif Proses, Keterampialn, dan Profesi. Yogyakarta: Araska.

Mu’takif, A. 2011 Wartawan Handal Diburu Media Massa. Surabaya: CV. Garuda Mas Sejahtera.

Purwanitaninggrum, Emy, dkk. 2013. Membaca Cepat untuk menyimpulkan Isi Bacaan Menggunakan Teknik Tayang Kilas dengan Media Film 
Terjemahan.http://journal.unnes.ac.i $\mathrm{d} / \mathrm{sju}$ /indeks.php/jpbsidiunduh pada tanggal 12 Desember 2018.

Rakhman, Meliana. 2010. Peningkatan Menyimpulkan Isi Cerita Anak Menggunakan Metode Kalimat Melalui Media Buku Cerita Bergambar Pada Peserta Didik Kelas V SD Muhamadiyah Danaraja Banjarnegara.

http://lib.unnes.ac.id/2979/1/6143.pd fdiunduh pada tanggal 12 Desember 2018.

Sanddhono, Kundharu, dan St. Y. Slamet. 2014. Pembelajaran Keterampilan Berbahasa Indonesia; Teori dan Aplikasi. Yogyakarta: Graha Ilmu.

Sudarman. 2008. Menulis di Media Massa. Yogyakarta: Pustaka Pelajar.

Sugiyono. 2015. Metode Penelitian Pendidikan (Pendekatan Kuantitatif, Kualitatif, dan $R \& D)$. Bandung: Alfabeta.

Wadaah, Fif'Atul. 2012. Peningkatan Kemampuan Menyimpulkan Isi Berita yang Dibacakan Melalui Metode Diskusi Pada Siswa Kelas VII SMP Negeri 31 Bandar Lampung Tahun Pelajaran 2012/2013.

digilib.unila.ac.id/6988/1/PTK.Rif'A tul Wadaah.pdfdiunduh pada tanggal 12 Desember 2018. 